\title{
Identifikasi Modal Sosial Masyarakat Terhadap Restorasi Lahan Pasca Tambang (Studi Masyarakat Desa Bukit Kijang, Kecamatan Namang, Kabupaten Bangka Tengah)
}

\author{
Herdiyanti S.Sos., M.Si \\ (vhiedyan@yahoo.co.id)
}

\begin{abstract}
Abstrak
Modal sosial merupakan salah instrument penting yang sangat memiliki pengaruh terhadap kehidupan masyarakat secara sosial dan ekonomi. Pembangunan ekonomi dasawarsa ini menjadi perhatian yang menarik bagi semua kalangan masyarakat terutama pemerintah dalam mewujudkan kesejahteraan masyarakat. Realitas ini berkaitan pada fokus kajian penelitian ini mengenai program restorasi lahan pasca tambang yang sedang berlangsung di Desa Bukit Kijang. Penelitian ini menggunakan metode penelitian kualitatif dengan pendekatan studi kasus. Sementara itu penelitian ini menggunakan teori dari tokoh James Coleman mengenai konsep modal sosial. Adapun tujuan dari penelitian ini untuk mengidentifikasikan modal sosial dalam kehidupan masyarakat Desa Bukit Kijang terhadap program restorasi lahan pasca tambang yang sedang berlangsung di desa tersebut. Hasil penelitian menunjukkan bahwa rendahnya modal sosial yang ada di masyarakat Desa Bukit Kijang. Beberapa indikator modal sosial yang dapat dijabarkan seperti rendahnya partisipasi masyarakat terhadap program restorasi lahan pasca tambang, rendahnya arus informasi seperti tidak berjalannya komunikasi yang efektif di masyarakat Desa Bukit Kijang. Selain itu, rendahnya hubungan sosial yang ada di masyarakat, seperti kurangnya partisipasi masyarakat terhadap pelaksanaan program yang dipelopori oleh Pemerintah Kabupaten Bangka dan Kementrian Lingkungan Hidup serta pihak swasta yang terlibat dengan program tersebut.
\end{abstract}

Kata Kunci : Modal Sosial, Restorasi Lahan, Pasca Tambang.

\section{Abstract}

Social capital is one of the most important instruments that have an influence on social life and economy. The economic development of this decade becomes an interesting concern for all society, especially the government in realizing the welfare of society. This reality is related to the focus of this study review of the ongoing post-mining land restoration program in Bukit Kijang Village. This research uses qualitative research method with case study approach. Meanwhile, this research uses the theory of the character James Coleman about the concept of social capital. The purpose of this study is to identify social capital in the community life of Bukit Kijang Village to the ongoing post-mining restoration program in the village. The results showed that the low social capital in Bukit Kijang Village community. Some social capital indicators can be elaborated such as low community participation in post-mining restoration program, low information flow such as ineffective communication in Bukit Kijang Village community. In addition, the low social relationships that exist in the community, such as the lack of community participation on the implementation of programs pioneered by the Government of Bangka Regency and the Ministry of Environment and the private parties involved with the program.

Keywords: Social Capital, Land Restoration, Post Mine. 


\section{A. Pendahuluan}

Bangka Belitung merupakan salah satu Provinsi yang memiliki kekayaan alam yang cukup potensial untuk dikembangkan terutama kaitannya terhadap pembangunan ekonomi. Pembangunan ekonomi masyarakat mayoritas berasal dari aktivitas pertambangan. Pertambangan timah merupakan salah satu potensi alam yang dikembangkan masyarakat dalam keberlangsungan penghidupan saat ini. Kondisi pasca timah mengundang banyak hal terutama bagi masyarakat agar mampu mengembangkan strategi apa yang dapat dilakukan dalam melangsungkan kehidupan pasca timah.

Sementara itu persoalan pasca timah ini juga mengundang beberapa upaya yakni antara Aparatur Desa seperti Kepala Desa Bukit Kijang beserta stafnya, tokoh masyarakat dan ketua kelompok tani serta Pemerintah Provinsi dan Kabupaten Bangka Tengah melakukan alternatif terhadap kesejahteraan masyarakat terkait dengan mata pencahariannya pasca timah dengan berbagai macam program restorasi lahan pasca tambang yang dilakukan. Desa Bukit Kijang, Kecamatan Namang, Kabupaten Bangka Tengah merupakan salah satu desa yang dikatakan sebagai desa baru dan sumber mata pencaharian masyarakatnya variatif. Bukit Kijang merupakan salah satu desa yang memiliki sejarah yakni merupakan gabungan antara dua dusun yaitu dusun Batu Kijang dan dusun Bukit Lesung yang kemudian menjadi Desa Bukit Kijang. Desa Bukit Kijang memiliki $300 \mathrm{KK}$ dan jumlah penduduk sebanyak 1177 jiwa yakni laki-laki sejumlah 675 jiwa sedangkan perempuan sejumlah 502 jiwa $^{1}$.

Desa ini sering kali menjadi sorotan media karena berbagai macam program pemerintah yang sedang berlangsung di desa tersebut. Salah satu programnya antara lain seperti restorasi lahan pasca tambang yang ditanami berbagai macam sayuran seperti cabai dan jagung. Program ini berlangsung efektif jika disertai adanya partisipasi masyarakat dalam menggerakkan program tersebut. Partisipasi masyarakat dibu-

1 Sumber data : Data Desa Tahun 2016 tuhkan dalam pembangunan ekonomi masyarakat khususnya. Sebagian dari masyarakat sudah mengalami transformasi terhadap aktivitas mata pencaharian dari tambang ke pertanian dan perkebunan. Menurut Supriyadi (2007:20) menjelaskan bahwa mata pencaharian merupakan sumber pekerjaan utama yang dilakukan individu untuk melangsungkan kehidupan dengan cara memanfaatkan berbagai macam aset penghidupan yang tersedia di lingkungan tempat tinggal. Salah satu alternatif yang dapat dikembangkan terutama mengenai kesejahteraan masyarakat desa yakni pembangunan ekonomi secara kompleksitas. Program yang dicanangkan oleh pemerintah merupakan salah satu pemberdayaan kepada masyarakat Desa Bukit Kijang. Pemberdayaan merupakan salah satu tujuan agar meningkatnya kemampuan masyarakat dari berbagai aspek. Pemberdayaan yang dilakukan tidak hanya didukung adanya modal ekonomi dan fisik saja, namun adanya dukungan modal-modal lainnya yang bekerja seperti modal alam, manusia dan sosial.

Pembangunan ekonomi dapat ditandai dengan adanya pembangunan fisik. Pembangunan fisik yang terjadi karena adanya dukungan modal manusia. Modal manusia yang berkembang karena adanya penopang yakni modal sosial yang menjadi asset penting dalam membangun ekonomi masyarakat. Modal Sosial memiliki peranan penting dalam proses pembangunan ekonomi masyarakat, pernyataan ini didukung oleh Mawardi (2007) mengemukakan bahwa dalam pelaksanaan pemberdayaan masyarakat sering kali menekankan pada modal alam dan ekonomi namun mengabaikan modal sosial yakni kelembagaan lokal, kearifan lokal, norma dan nilai masyarakat serta partisipasi masyarakat sebagai penopang terlaksananya pemberdayaan masyarakat. . Modal sosial memiliki perbedaan dengan modal-modal lainnya. Modal sosial merupakan perekat dalam menggerakkan modal lainnya.

Modal sosial merupakan konsep yang sangat penting dalam menunjang model pembangunan yakni manusia. Manusia merupakan subjek yang 
menentukan dan menggerakkan penyelenggaraan pembangunan masyarakat desa. Modal sosial merupakan kemampuan seseorang atau komunitas dalam memanfaatkan sumberdaya yang terdapat pada lingkungan masyarakat. Modal sosial menurut Coleman (1990) yakni merupakan akses yang sesungguhnya memiliki peranan secara ekonomi untuk meningkatkan kelangsungan penghidupan masyarakat. Menurut Coleman di dalam modal sosial terdapat dua ikatan yang saling berhubungan yakni mengikat dan menjembatani.

\section{B. Rumusan Masalah}

Pada hakekatnya modal sosial merupakan salah satu instrument penting dalam meningkatkan program pemerintah demi pembangunan ekonomi masyarakat. Singkat jelas tujuan dari penelitian ini mengacu pada uraian di atas dapat dirumuskan masalah yakni Bagaimana peran modal sosial pada masyarakat Desa Bukit Kijang terhadap Program Restorasi Lahan Pasca Tambang?

\section{Kerangka Teoritis}

Menurut James Coleman (John Field:2013) menjelaskan bahwa konsep modal sosial merupakan sarana dalam menjelaskan bagaimana seseorang atau komunitas dalam melakukan kerjasama. Kepercayaan merupakan salah satu intrumen modal sosial yang dibentuk dalam kehidupan masyarakat atau komunitas. Kepercayaan yang tumbuh didorong dengan adanya kesamaan nasib dan tujuan dalam mencapai tujuan tertentu, sehingga memaksa individu atau masyarakat untuk melakukan kerjasama. Menurut Coleman terdapat dua ikatan yang saling mengikat antara internal dan eksternal atau Bonding Social Capital dan Bridging Social Capital dalam kehidupan masyarakat atau komunitas. Bonding dan Bridging bekerja saling bersinergis dalam kehidupan masyarakat. Adapun pemahaman Coleman dalam tulisannya yang berjudul "social capital in the creation of human capital"(1988) menjelaskan bahwa modal sosial sebagai sarana konseptual yang menjelaskan tindakan sosial secara teoritis dengan mengaitkan perspektif sosiologi dan ekonomi. Coleman berpendapat bahwa pengertian modal sosial ditentukan oleh fungsinya. Sekalipun sebenarnya terdapat banyak fungsi modal sosial tetapi ia mengatakan bahwa pada dasarnya semuanya memiliki dua unsur yang sama, yakni: pertama, (1) modal sosial mencakup sejumlah aspek dari struktur sosial, dan (2) modal sosial memberi kemudahan bagi orang untuk melakukan sesuatu dalam kerangka struktur sosial tersebut. Selain itu Coleman mengidentifikasi terdapat tiga unsur utama yang merupakan pilar modal sosial. Pertama berkaitan terhadap kewajiban dan harapan merupakan kemunculan dari rasa saling percaya atau kepercayaan dalam lingkungan sosial masyarakat. Kemudian pilar kedua modal sosial menurut Coleman adalah pentingnya arus informasi dalam bentuk komunikasi yang lancar di dalam struktur sosial sehingga dapat mendorong berkembangnya kegiatan dalam masyarakat. Menjadi penting diketahui bahwa arus informasi yang tidak lancar cenderung menyebabkan orang menjadi tidak tahu atau ragu-ragu sehingga tidak berani melakukan sesuatu. Arus informasi merupakan salah satu bentuk interaksi sosial masyarakat. Pilar ketiga adalah norma-norma yang harus ditaati dengan sanksi yang jelas. Tanpa adanya seperangkat norma yang disepakati dan dipatuhi oleh segenap anggota masyarakat maka yang muncul adalah keadaan anomie dimana setiap orang cenderung berbuat menurut kemauan sendiri tanpa merasa ada ikatan dengan orang lain. Juga tidak ada mekanisme untuk menjatuhkan sanksi karena tidak ada norma yang disepakati bersama berkaitan dengan sanksi tersebut. Dengan demikian pengembangan modal sosial pada dasarnya ditujukan untuk membangun ketiga pilar yang dimaksudkan Coleman itu.

\section{Kajian Pustaka}

Modal Sosial Dalam Perspektif Kebijakan Publik Edi Suharto, PhD (2005) dalam artikelnya menjelaskan bahwa kebijakan public yang di dalamnya terdapat kebijakan sosial dapat 
dijadikan sebagai suatu instrument penting suatu negara dalam membangun dan meningkatkan modal sosial dalam suatu masyarakat. Pemerintah dapat menciptakan kondisi dengan berbagai daya dukung modal sosial yang ada pada masyarakat maupun komunitas untuk menjalankan berbagai macam program yang berkaitan erat dengan pembangunan ekonomi masyarakat setempat. Program yang dilakukan oleh pemerintah pada masyarakat tertentu menjadi ukuran terhadap eksistensi modal sosial masyarakat setempat. Menurut Edi Suharto bahwa keberhasilan program pemerintah terhadap kesejahteraan masyarakat tertentu didukung adanya modal sosial yang bekerja di dalam masyarakat tersebut dalam melangsungkan program pemerintah. Keikutsertaan atau partisipasi masyarakat menjadi penopang keberhasilan program pemerintah. Selanjutnya pada penelitian Wedy Nasrul, Nursyirwan Effendi, Yonariza, Melinda Noer (2015) sama halnya dengan penelitian sebelumnya menggambarkan bentuk-bentuk modal sosial apa saja yang berpotensi melindungi pasar tradisional gambir sebagai dukungan sosial untuk melindungi dan memberdaya pasar gambir. Berdasarkan hasil temuan di lapangan, ditemukan bentuk kerja sama dan tindakan kolektif yang merupakan kunci terciptanya dukungan sosial dari kelembagaan lokalyang terlibat untuk melindungi pasar tradisional gambir. Kedua penelitian ini memiliki kesamaan analisis kasus yaitu dihadirkan bentuk antisipasi dalam menghadapi kendala-kendala yang akan muncul jika modal sosial tidak bisa dipertahankan dan dilestarikan keutuhannya atau dapat dikatakan melemah. Sehingga warga yang terlibat pada pasar tradisional gambir harus mampu melakukan antisipasi dalam menghadapi tantangan dan kendala-kendala yang dapat menjadi ancaman warga dalam melindungi eksistensi pasar tradisional gambir. Gambaran yang dapat direfleksikan secara kritis terhadap dua penelitian di atas bahwa pentingnya modal sosial dibangun dan dikembangkan dalam kehidupan masyarakat terutama berkaitan terhadap pembangunan ekonomi masyarakat. Hal ini sejalan dengan pemikiran Coleman sebagaimana telah diuraikan sebelumnya bahwa "pilar utama modal sosial berupa struktur sosial yang menciptakan pengungkungan dalam sebuah jaringan sosial yang membuat setiap orang saling berhubungan sedemikian rupa, sehingga kewajiban-kewajiban maupun sanksi-sanksi dapat dikenakan kepada setiap orang yang menjadi anggota jaringan itu" (Coleman, 1988).

\section{E. Metodologi}

Penelitian ini menggunakan metode penelitian kualitatif dengan pendekatan studi kasus serta menggunakan metode pengumpulan data berupa observasi, wawancara mendalam (indefth interview) dan dokumentasi. Teknik analisa data yang digunakan adalah deskriptif kualitatif terhadap suatu kasus yang diteliti mengenai tentang peran modal sosial terhadap program restorasi lahan pasca tambang yang dilakukan oleh Pemerintah Kabupaten Bangka Tengah yang bekerja sama dengan Kementrian Lingkungan. Penelitian ini menggunakan strategi survey dan pengamatan secara langsung di lokasi penelitian Desa Bukit Kijang. Hal ini dilakukan agar memperoleh gambaran umum mengenai Desa Bukit Kijang baik dari demografi desa, sumber mata pencaharian dan karakter penduduk serta dinamika interaksi yang berlangsung terhadap program yang ada di Desa Bukit Kijang. Tahapan selanjutnya yang dilakukan merujuk pada pemikiran Cresswell (2010) yang memiliki tujuan membantu peneliti pada saat proses turun lapangan. Selanjutnya, implementasi dari tahapan penelitian yang dilakukan memiliki dampak terhadap proses penelitian. Adapun proses penelitian yang akan dilakukan dalam penelitian ini. Peneliti membawa konsep yang telah disusun sebelum turun lapangan, konsep yang diusung terlebih dahulu ini bukanlah bentuk hipotesis yang hendak dibuktikan di hasil penelitian, namun lebih sebagai mediator yang akan dinegosiasikan ulang bedasarkan temuan lapangan atau diskursus yang didapatkan mengenai peran modal sosial terhadap program restorasi lahan pasca tambang. Proses pengumpulan data diperoleh melalui eksperimen, pengamatan/observasi, historis dan 
teknik wawancara mendalam (indepth interview), selain itu penelitian ini melakukan Focus Group Discussion (FGD) terhadap stakeholder masyarakat Desa Bukit Kijang seperti Kepala Desa, Tokoh Masyarakat, Insinyur (stakeholder pemerintah). Teknik pengumpulan data dilakukan secara deskriptif tentang hasil temuan lapangan mengenai fenomena masyarakat Desa Bukit Kijang terhadap program pemerintah yang sedang berlangsung di desa tersebut. Analisis deskriptif dilakukan bertujuan untuk menghasilkan gambaran dari data yang telah terkumpul berdasarkan hasil wawancara dari sejumlah informan baik informan kunci maupun biasa yang memiliki sudut pandang berbeda. Adapun strategi penelitian yang dilakukan dalam penelitian ini yakni diawali dengan melakukan pengamatan secara langsung bagaimana kondisi Desa Bukit Kijang. Sehingga dapat diperoleh gambaran umum desa tersebut baik dari demografi desa, sumber mata pencaharian dan karakter penduduk serta dinamika interaksi yang berlangsung di Desa Bukit Kijang. Selanjutnya, mengunjungi kantor Kepala Desa Bukit Kijang dan melakukan wawancara secara mendalam.

\section{F. Hasil dan Pembahasan}

Pada bab ini peneliti mengupas dan mendeskripsikan temuan di lapangan dalam menjawab rumusan masalah yang telah dikaji dan diperoleh di lapangan. Identifikasi modal sosial dapat dipicu adanya beberapa indikator yang terjadi di masyarakat Desa Bukit Kijang, Kecamatan Namang, Kabupaten Bangka Tengah. Tipologi modal sosial yang ditemukan pada masyarakat desa tersebut dapat dijabarkan sebagai berikut :

\section{Partisipasi Masyarakat Desa Bukit Kijang}

Partisipasi merupakan salah satu indikator dari modal sosial yang dapat ditemukan pada masyarakat desa maupun kota. Partisipasi menurut Coleman merupakan salah satu yang ditandai adanya interaksi yang dilakukan secara berulang dan intens oleh individu atau komunitas masyarakat. Partisipasi merupakan salah satu indikator yang mendukung keberhasilan dari program yang sedang berlangsung di Desa Bukit Kijang. Berdasarkan hasil penelitian dan wawancara dari beberapa informan di lapangan bahwa masyarakat memiliki tingkat partisipasi yang rendah terhadap program yang sedang berlangsung di Desa Bukit Kijang. Hal ini dikarenakan kurangnya interaksi dan pemahaman masyarakat untuk bisa berpartisipasi guna dalam membangun ekonomi masyarakat berbasiskan kearifan lingkungan. Selain itu, kurangnya pemberdayaan yang dilakukan oleh aparatur Desa Bukit Kijang kepada masyarakat dalam merespon program Pemerintah Kabupaten Bangka Tengah. Hal ini disebabkan sinergisitas antara Top Down (Bridging dan Linking) dan Bottom Up (Bonding) masih sangat rendah. Kolektifitas antara Top Down dan Bottom Up tentunya dapat menciptakan sikap partisipasi yang tinggi dalam membangun kemajuan Desa Bukit Kijang.

Berdasarkan hasil wawancara dengan salah satu stakeholder penting di desa menjelaskan bahwa masyarakat di desa kurang aktif dalam melakukan kegiatan pertanian, apalagi dengan adanya program pemerintah terhadap restorasi lahan pasca tambang yang bekerjasama dengan pihak swasta seharusnya keterlibatan masyarakat sangat dibutuhkan ${ }^{2}$. Namun masyarakat cenderung lebih memprioritaskan sumber mata pencaharian sektor tambang di Desa Bukit Kijang. Sumber mata pencaharian sektor tambang dirasakan lebih menguntung dan membantu perekonomiannya dibandingkan pertanian. Namun, hal ini hanya bersifat sementara dan tidak berkelanjutan. Masyarakat tidak menyadari secara langsung akibat dari aktivitas tambang yang dilakukan dapat menyebabkan kerusakan lingkungan di Desa Bukit Kijang. Selain itu, masyarakat

2 Sumber data : Informan Insinyur Dari Bogor Pak Didik (Januari 2017) 
juga kurang memanfaatkan potensi-potensi yang dimiliki di Desa Bukit Kijang. Adapun potensi yang dimiliki pada masyarakat ini yakni agrowisata multicultural dan home industri.

Sementara itu rendahnya partisipasi yang terjadi juga disebabkan kurangnya sosialisasi dari aparatur desa dalam mengelola dan membina masyarakat desa tersebut. Seyogyanya masyarakat akan dapat mengalami perubahan sosial apabila didukung adanya komunikasi yang interaktif dalam membangun perkembangan desa. Komunikasi yang interaktif maksudnya adalah komunikasi yang dipola secara berkelanjutan dengan pihak warga. Hal yang dapat mendorong terciptanya partisipasi sosial masyarakat seperti arus informasi yang lebih intens melalui komunikasi dengan masyarakat. Komunikasi dan sosialisasi pemahaman merupakan salah satu tindakan efektif dalam membangun struktur sosial di masyarakat Desa Bukit Kijang. Menurut Coleman jika arus informasi tidak lancar akan menyebabkan masyarakat menjadi apatis dan rendahnya rasa saling percaya. Sehingga akan berpengaruh terhadap program restorasi lahan pasca tambang yang sedang berlangsung di desa tersebut.

Sehingga adapun komunikasi dan sosialisasi yang dilakukan tidak hanya bermanfaat, namun berkelanjutan dan juga memberikan pengetahuan dan pemahaman bagi masyarakat untuk dapat menjaga lingkungan di Desa Bukit Kijang. Pengetahuan dan pemahaman yang diperoleh oleh masyarakat lambat laun dapat mengubah pola pikir masyarakat setempat dalam mengelola lingkungan secara baik dan tepat.

\section{Rasa Saling Percaya}

Coleman menjelaskan bahwa dalam merepresentasikan sumberdaya melalui hubungan-hubungan yang dibangun dan diatur oleh tingginya tingkat kepercayaan dan nilai-nilai bersama yang dimiliki oleh masyarakat. Tingkat kepercayaan yang tinggi menjadi ukuran terhadap suatu keberhasilan pembangunan ekonomi masyarakat namun sebaliknya tingkat kepercayaan yang rendah menjadi penghambat terhadap keberhasilan pembangunan ekonomi masyarakat. Coleman menjelaskan bahwa pilihan rasional menjadi tolak ukur terhadap tinggi rendahnya tingkat kepercayaan seseorang dalam membangun kerjasama. Coleman menjelaskan teori pilihan rasional sangat bersifat individualistic yang memungkinkan seseorang memfilter hubungan untuk melakukan kerjasama. Berdasarkan hasil penelitian di lapangan dan penjelasan dari salah satu informan kunci yakni Kepala Desa menjelaskan bahwa mayoritas dari masyarakat Desa Bukit Kijang memiliki rasa kecurigaan tinggi terhadap program yang sedang berlangsung di desa ini. Peneliti dapat menganalisa bahwa kecurigaan yang muncul akibat dari kurangnya pola interaksi dan partisipasi yang dibangun oleh masyarakat sehingga memunculkan rasa kekhawatiran dari masyarakat Desa Bukit Kijang. Kecurigaan yang muncul mengakibatkan masyarakat enggan untuk bisa berpartisipasi terhadap program yang sedang berlangsung di desa tersebut. Masyarakat memiliki pilihan yang dianggap rasional dapat membantu perekonomiannya dengan cara bertambang atau ngelimbang dibandingkan berpartisipasi pada program Pemerintah Kabupaten Bangka Tengah. Berdasarkan pernyataan dari beberapa informan menjelaskan bahwa mereka lebih cenderung mencari nafkah untuk kebutuhan ekonomi dengan cara ngelimbang timah. Masyarakat tidak menyadari secara langsung bahwa di Desa Bukit Kijang memiliki potensi yang dapat dikembangkan dalam membangun perekonomian masyarakat. Potensi-potensi yang dapat dikembangkan yakni antara lain seperti Agrowisata multicultural merupakan salah satu potensi yang dapat dikembangkan oleh masyarakat mengenai lahan pasca 
tambang yang dapat dijadikan sebagai lahan pertanian. Proses restorasi lahan pasca tambang ini di miliki oleh dua pemilik modal, yaitu lahan 8 hektar dimiliki oleh Kementerian Pertanian Bangka Tengah dan Kementerian Pertanian Bogor dan bekerja sama dengan gapoktan Bukit Kijang. Selain itu lahan 10 hektar juga dimiliki oleh PT Timah dan Polda yang bekerja sama dengan Gapoktan Desa Bukit Kijang dengan jumlah anggota sebanyak 10 anggota ${ }^{3}$. Selanjutnya home industry salah satu potensi yang menarik untuk dikembangkan yaitu keterampilan masyarakat dalam memproduksi gula merah, sapu kulit kelapa, keripik lumpia dan kemplang. Berbagai kegiatan produksi (home industri) yang dilakukan masyarakat Desa Bukit Kijang seperti gula merah, dengan bahan pokok air kabung dari pohon beluluk, sapu dari sisa kulit kelapa tua (sabut), serta keripik lumpia dan kemplang yang mereka produksi dari buah belinju dan ubi kayu. Hal ini cukup membuktikan adanya keterampilan yang dapat dikembangkan dan perlu perhatian dari pemerintah desa dan pemerintah daerah setempat.

\section{Kerja Sama}

Kerja sama merupakan salah satu elemen modal sosial yang dapat mendukung terjadinya pola interaksi yang dilakukan secara berulang baik dari pihak internal maupun eksternal. Seperti halnya yang dipaparkan oleh Coleman bahwa trust atau rasa saling percaya menjadi kekuatan atau basisnya dalam mencapai tujuan bersama (John Fiel:2013). Rasa saling percaya akan memudahkan seseorang atau komunitas masyarakat dalam membangun kerjasama. Analisis Coleman tentang pilihan rasional menjadi factor dalam menentukan hubungan kerjasama antara satu dengan yang lainnya. Jika terjadi kerjasama makan tidak serta

3 Sumber data Desa Bukit Kijang 2016 merta kerjasama yang terbentuk berdasarkan kepentingan bersama, namun atas dasar kepentingan individu.

Kerjasama tidak akan terbentuk jika tidak memiliki rasa saling percaya antar sesama dari berbagai pihak. Trust yang dibangun oleh masyarakat merupakan bagian dari energi pembangunan ekonomi dalam masyarakat Desa Bukit Kijang. Sama halnya trust merupakan bagian dari unsur modal sosial yang dapat dijadikan sumber kekuatan dalam mempertahankan keberlangsungan penghidupan masyarakat dalam kurun waktu jangka panjang. Jika adanya rasa saling percaya maka akan terbentuk komunikasi yang efektif antara aparatur desa serta stakeholder lainnya dengan warga mengenai pentingnya menjalankan program pemerintah dengan mengikutsertakan partisipasi masyarakat dalam membangun ekonomi masyarakat yang berbasis kearifan lingkungan di Desa Bukit Kijang. Berdasarkan hasil penelitian di lapangan beberapa informan yakni sekretaris desa dan insinyur dari Kementrian Pertanian Bogor menjelaskan bahwa untuk membangun dan meningkatkan ikatan kerjasama dengan masyarakat mengalami hambatan. Hubungan yang terbentuk antara Aparatur Desa, Pemerintah Kabupaten Bangka Tengah dan Kementrian Pertanian Bogor hanya beberapa dari masyarakat Desa Bukit Kijang. Beberapa dari masyarakat tersebut masih bisa dihitung kapasitasnya yakni sebanyak 10 orang $^{4}$ yang berpartisipasi dan peduli dengan lingkungannya. Realitas ini perlu perhatian penting bagi aparatur desa untuk dapat meningkatkan hubungan kerjasama antara warga dan para stakeholder terhadap program pemerintah melalui penyuluhan dan sosialisasi kepada masyarakat bahwa pentingnya untuk membangun relasi dan kerjasama serta berpartisipasi pada setiap kegiatan atau program yang dilakukan oleh

4 Hasil wawancara Sekretaris Desa Bukit Kijang (Februari 2017) 
Pemerintah Kabupaten Bangka Tengah. Sementara itu terkait dengan norma masyarakat yang ada di Desa Bukit Kijang kurang dipatuhi dan dijalankan oleh sebagian masyarakat setempat. Norma merupakan salah satu produk atau elemen modal sosial yang melekat pada kehidupan masyarakat baik perdesaan maupun perkotaan. Norma merupakan salah satu aturan yang disepakati dan dipatuhi secara bersama oleh masyarakat tertentu dalam menjalankan kehidupan. Berdasarkan hasil wawancara dan realitas yang terjadi di lapangan meskipun aktivitas tambang dilarang oleh aparatur desa namun masih ada sebagian dari masyarakat melakukan aktivitas tambang sebagai sumber mata pencaharian. Hal ini disebabkan karena factor ekonomi yang mendesak sebagian dari masyarakat melakukan aktivitas tersebut. Aturan yang ada seperti dilarang untuk melakukan aktivitas tambang di sekitaran wilayah desa tidak dijalankan dan dipatuhi oleh sebagian masyarakat ${ }^{5}$. Sehingga hal tersebut berdampak pada kondisi lingkungan yang lambat laun menjadi rusak.

\section{G. Analisis Data}

Pembahasan bab sebelumnya mengantarkan pada sebuah refleksi kritis terhadap kondisi yang ada di Desa Bukit Kijang. Realitas yang menarik untuk dianalisa secara kritis berdasarkan perolehan data di lapangan bahwa ditemukan peran modal sosial tidak bekerja secara efektif baik bonding dan bridging social capitalnya, hal ini disebabkan karena masih rendahnya partisipasi masyarakat terhadap pembangunan Desa Bukit Kijang. Rendahnya partisipasi masyarakat memberikan pengaruh secara tidak langsung terhadap elemen-elemen modal sosial lainnya seperti pola interaksi, rasa saling percaya dan kerjasama. Oleh karenanya sulit bagi aparatur desa dalam membangun komunikasi dengan masyarakat setempat untuk mensinergisitaskan hubungan antara masyarakat dengan pihak-

5 Hasil wawancara Kepala Desa (3 Maret 2017) pihak yang terlibat dalam program restorasi lahan pasca tambang. Program restorasi lahan pasca tambang merupakan salah satu program yang dilakukan oleh Kementrian Lingkungan Hidup yang bekerjasama dengan Aparatur Desa Bukit Kijang untuk memulihkan lahan-lahan pasca tambang dengan ditanami berbagai macam tanaman seperti cabai dan jagung berdasarkan uji kesuburan tanah yang dilakukan oleh salah satu insinyur tanah dari Bogor yakni Pak Didik beserta rekannya yang lain. Namun, pola pikir masyarakat belum seluruhnya terbuka (open minded) terhadap pembangunan yang ada di Desa Bukit Kijang saat ini. Salah satu penyebabnya adalah kurangnya rasa memiliki dan peduli terhadap kelestarian lingkungan sangat rendah karena masyarakat hanya memprioritaskan kepentingan ekonomi dalam melangsungkan kehidupannya tanpa menghiraukan dampak dari aktivitas yang dilakukannya pada masa mendatang untuk generasi berikutnya.

Sinergisitas antara top down dan bottom up tidak berjalan efektif dikarenakan kurangnya partisipasi masyarakat. Partisipasi masyarakat hanya segelincir saja yang berasal dari aparatur desa. Masyarakat di luar struktur desa kurang begitu peduli dan berpatisipasi terhadap program restorasi lahan pasca tambang yang dilakukan oleh Kementrian Lingkungan Hidup, Kabupaten Bangka Tengah serta pihak swasta yakni PT. Timah. Sementara itu, program yang ada masih berlangsung meskipun hanya sebagian masyarakat yang berpartisipasi terhadap program tersebut. Berdasarkan temuan di lapangan salah satu informan menjelaskan bahwa diharapkan agar masyarakat dapat berpartisipasi dan peduli dengan lingkungan di Desa Bukit Kijang. Partisipasi masyarakat sangat membantu pemerintah dalam membangun desa tersebut ${ }^{6}$. Partisipasi merupakan elemen modal sosial yang sangat memiliki fungsi penting dalam kehidupan masyarakat. Berdasarkan analisa Coleman bahwa seseorang yang tidak memiliki modal sosial maka akan sulit menjalinkan hubungan dengan

6 Hasil wawancara : Pak Didik (3 Maret 2017) 
pihak manapun. Artinya rendahnya pola interaksi dan partisipasi masyarakat maka sulit mencapai keuntungan materiil dan keberhasilan secara optimal.

\section{H. Penutup}

Peran modal sosial pada masyarakat Desa Bukit Kijang terhadap program restorasi lahan pasca tambang cukup menjadi perhatian penting bagi semua kalangan, baik masyarakat internal desa maupun pemerintah beserta stakeholder yang terlibat terhadap program yang sedang berlangsung di Desa Bukit Kijang. Berdasarkan temuan di lapangan dapat dideskripsikan kondisi sosial masyarakat desa tersebut bahwa dinamika hubungan atau relasi sosial yang terjadi di desa tidak berjalan efektif. Hal ini disebabkan karena rendahnya rasa saling percaya masyarakat internal desa dengan berbagai pihak pemerintah maupun stakeholder yang menjadi monitoring program restorasi lahan pasca tambang. Kepercayaan menjadi ukuran keberhasilan terhadap restorasi lahan pasca tambang yang merupakan model pembangunan desa menuju desa sejahtera berbasis kearifan lingkungan. Namun, realitas yang terjadi menjadi tolak ukur bahwa lingkungan menjadi korban akibat intervensi masyarakat demi mencapai kebutuhan ekonomi. Program restorasi lahan pasca tambang merupakan salah satu upaya pemulihan dan pemberdayaan terhadap kerusakan lingkungan yang semakin hari semakin memprihatinkan yang dipelopori oleh Pemerintah Daerah Kabupaten Bangka Tengah yang bekerjasama dengan Kementrian Lingkungan Hidup serta PT. Timah Tbk. Selain rendahnya tingkat kepercayaan yang menyebabkan kurangnya partisipasi masyarakat yakni kurangnya koordinasi atau arus informasi yang disampaikan oleh pihak Aparatur Desa Bukit Kijang dalam melakukan sosialisasi pentingnya partisipasi masyarakat dalam membantu dan menjalankan program restorasi lahan pasca tambang di Desa Bukit Kijang. Meskipun pernah dilakukan sosialisasi namun partisipasi masyarakat juga masih tetap rendah. Hal ini memunculkan beberapa masukan dan saran bahwa sosialisasi yang dilakukan harus dilakukan secara rutin dan dikoordinir masing-masing RT yang ada di desa maupun dusun. Sehingga kondisi tersebut menciptakan komunikasi yang intens antara aparatur desa dengan masyarakat beserta stakeholder yang terkait terhadap program restorasi lahan pasca tambang.

\section{Daftar Pustaka}

Coleman, James S. 1988. Social Capital in the Creation of Human Capital'American Journal of Sociology 94: S95-S120.

Coleman, James S. 1990. Foundations of Social Theory. Cambridge, Mass: Harvard University Press.

Creswell W. Jhon. 2010. Research Design; Pendekatan Kualitatif, Kuantitatif dan Mixed. Yogyakarta: Pustaka Pelajar.

Field, John. 2013. Modal Sosial. Yogyakarta.: Kreasi Wacana.

Mawardi, M.J. 2007. Peranan Social Capital Dalam Pemberdayaan Masyarakat. Komunitas 2, Jurnal Pengembangan Masyarakat Islam.

Wahyu, Supriyadi Waskito. 2007. Pergeseran Mata Pencaharian Masyarakat Desa. FISIP: UNS.

\section{Penelitian}

Nasrul, Wedy dkk. 2015. Dukungan Modal Sosial dari Kelembagaan Lokal untuk Melindungi Pasar tradisional Gambir. Padang: Universitas Andalas.

Suharto, Edi. 2005. Analisis Kebijakan Publik: Panduan Praktis Mengkaji Masalah Sosial dan Kebijakan Sosial. Bandung: Alfabeta. 